\title{
Automatic Leviathan: Cybernetics and politics in Carl Schmitt's postwar writings
}

History of the Human Sciences 2020, Vol. 33(I) I28-146 (C) The Author(s) 2020

Article reuse guidelines: sagepub.com/journals-permissions DOI: 10.1 | 777/0952695 | | 9864244 journals.sagepub.com/home/hhs

@SAGE

\section{Nicolas Guilhot}

Centre de Recherches Sociologiques et Politiques de Paris (CRESPPA), CNRS, France

\begin{abstract}
This article questions the current vogue of Carl Schmitt among political theorists who read him as an antidote to the depoliticizing force of economics and technology in the age of neoliberalism and its algorithmic rationalities. It takes Schmitt's sparse reflections about cybernetics and game theory as paradigmatic of the theoretical and political problems raised by any theory positing the autonomy of the political. It suggests that this ultimately misunderstands the role of cybernetic representations of political decisionmaking in shoring up in the 1960s and 1970s the autonomy of the political that Schmitt so vehemently defended.
\end{abstract}

\section{Keywords}

cybernetics, decisionism, industrial society, Carl Schmitt, technology

\begin{abstract}
Souverän ist, wer über die höchste Wirksamheit der in einer Gesellschaft angewandten wissenschaftlich-technischen Mittel verfügt [Sovereign is he who has at his disposal the most efficient techno-scientific means used in a society].
\end{abstract}

(Schelsky, 1961: 24)

\section{Corresponding author:}

Nicolas Guilhot, Centre de Recherches Sociologiques et Politiques de Paris (CRESPPA), 59-61 rue Pouchet, 75849 Paris Cedex 17, France.

Email: nicolas.guilhot@gmail.com 


\section{Introduction: From troll armies to motorized partisans}

The role of new technologies, and social networks in particular, in the recent populist upsurge raises afresh the question of the relationship between politics and technology. The strategic use of digital networking technologies, or the selective weaponization of transparency for the purpose of mass manipulation, certainly represents a stark rebuttal of irenic visions of the Internet as ushering in a transparent world of instantly and universally accessible knowledge enabling millions of users to become informed decision-makers in an open democracy. Far from simply freeing us from the mediating strictures of modern political representation and the centralization of decision-making, new technologies have also made possible new forms of domination and power. Notions such as 'cyber-war' or 'troll armies' point to hybrid entanglements of self-regulated cybernetic environments on the one hand, and vertical political command and sovereign orders on the other. There also seems to be a politics specific to these novel forms of technological engagement: More often than not, this comes from political forces that claim to defend or reinstate state sovereignty against the depoliticizing power of global markets and transnational circulations. To put it differently: Today, the autonomy of the political seems to be perfectly compatible with distributed sociotechnical networks.

How can we interpret these new techno-political assemblages? How have they transformed the traditional articulation of politics and technology? Some symptoms of this transformation are reflected in the changing cultural narratives surrounding the hacker. Initially tied to the counterculture of the 1960s and the defence of digital commons against the state and private property rights, hackers have been drawn into the force field of great-power politics and deployed as irregulars tasked with political infiltration and the manipulation of public opinion. The description of these foot soldiers of today's cyber-wars seems to have been provided long ago by Carl Schmitt in his analysis of the transformation of the partisan under conditions of technological globalization: Uprooted from his homeland and 'linked to an information network', the 'motorized' partisan was deployed in overt and covert wars by 'powerful central agencies of world politics'. He was a pawn opportunistically activated and deployed in global theatres by his remote handlers, who used him as 'a technician of the invisible struggle, a saboteur, and a spy' (Schmitt, 2007a: 76, 22).

If Schmitt's writings on politics and technology are credited with relevance today, it is because for a number of political thinkers they seem to indicate a way of countering the depoliticizing force of technologically embedded administrative and economic rationalities. As sovereignty over many domains of social life seems to be diluted in extended sociotechnical networks, how can the political be asserted anew? Can political decisions still be made when sophisticated technologies mediate all decision-making?

Yet, the central role of such technologies in the recent electoral victories of political forces claiming to reassert state sovereignty and the autonomy of politics should give pause to those who take at face value Schmittian dichotomies rather than seeing them as an elaborate political rhetoric. This paper questions the relevance of Schmitt's understanding of the techno-political nexus, while warning against current calls for restoring a political capacity allegedly eroded by technology or economics. Not only do such calls often drift back into political theology and a reactionary longing for a deus ex machina, 
but what they miss is that Schmitt failed to recognize the extent to which postwar industrial societies had deployed their technological apparatus precisely in order to shore up the autonomy of the political that he so vehemently defended. ${ }^{1}$ Despite occasionally acute insights, Schmitt's treatment of technology in the 1960s and 1970s remained ultimately conditioned by the conceptual framework he carried over from the 1930s, and inadequately captured the role of cybernetic decision-making systems in modern society. This is what ultimately mars any attempt at looking in Schmitt's political theory for ways of countering the regulation of social life by automated decision-making systems that seemingly cannot be ascribed to any identifiable form of sovereign power: Schmitt's desperate efforts at disentangling politics from technology stemmed from, but also hid the fact that the two had become inexorably conflated and mutually supportive.

I analyse Schmitt's writings from the 1960s and 1970s, a time when the question of the place and the forms of the political in a world increasingly unified by technicalindustrial means was a recurrent focus of his reflections and interventions. In particular, I pay attention to the small number of casual observations he made about cybernetics and game theory. The question of cybernetic systems (and other algorithmic decisionmaking technologies, such as game theory) is important because it exacerbates the tension between politics and technology that was the core of Schmitt's argument. Cybernetics is not just a particularly advanced form of technology; it is a form of technology that is very close to politics. In several respects, cybernetic systems are like state machineries and operate as if someone were making decisions: They neutralize conflicts internally; they respond to an external environment on the basis of a preexisting orientation; they strive for survival; and they seem to generate decisions. $\kappa \nu \beta \varepsilon ́ p \nu \eta \sigma \iota \varsigma$ is arguably one of the oldest sources of metaphors for government: steering in the sense of holding a rudder, the ship of state, the manus gubernatoris, and so on. Cybernetics seems indeed to be redundant with politics. On the other hand, the notion that the political represents an autonomous sphere has been, historically, the very basis upon which politics takes a rational, technical form (modern political science, for instance). It is no coincidence that reactionary thinkers have often considered politics not so much a social activity as a purely technical one (Malaparte, 2011). Schmitt himself had earlier defined the autonomy of the political that expressed itself in the institution of dictatorship as exclusively concerned with technical means and efficiency (Schmitt, 2014: 8). In the end, Schmitt's own 'decisionism' was as neutral and as content-independent as technology itself (Löwith, 1995).

It was precisely this symmetry and interchangeability that made cybernetic technologies so threatening to Schmitt's concept of the political. While some of Schmitt's epigones, like Helmut Schelsky, sensed that modern sovereignty was being transformed by the ubiquity of technical systems, Schmitt ultimately tried to locate politics outside and above the sociotechnical networks that provided its new medium. He never gave up on the existence of the political as a fundamental dimension of human life that was threatened by technology, yet could never be entirely displaced by it. His confidence in the resilience of his own concept of the political was possible precisely because he defined it both by its autonomy and by its capacity to permeate any social sphere, including technology. As a result, he could see technology as being simultaneously apolitical and the seemingly neutral mask of a specific politics. If technology was a 
depoliticizing force, it was because techno-industrial globalization was nothing but a politics to end all politics - a liberal form of politics that, as such, encountered political resistance. In this and other topics, this was one of Schmitt's signature moves. ${ }^{2}$

I explore Schmitt's evolving and sometimes elliptic reflections on the subject first by reconstructing the changing relationship between politics and technology in the postwar era as it was staged in Schmitt's analysis of the partisan. I then move on to Schmitt's efforts at salvaging a definition of politics as sovereign decision-making that could not be countenanced by cybernetic systems, using Hobbes as a terrain of choice to conduct this argument. Finally, I suggest that the constant effort at counterpoising technology to politics is what prevented Schmitt from realizing the extent to which the postwar decision sciences were actually tasked with shoring up the autonomy of the political, especially after the social upheavals of the 1960s, when cybernetics was seen as an effective response to the social overload of the state.

\section{Schmitt's networked partisan: Politics in the global techno-industrial age}

Theory of the Partisan originates from two lectures Schmitt gave in Spain in 1962. The subtitle, Intermediate Commentary on the Concept of the Political, located the discussion in the continuity of Schmitt's interwar disquisition on the meaning of the political. ${ }^{3}$ While the book dealt with military history, strategy, and philosophy, as well as legal and administrative aspects of partisanship, it was also a reflection on the transformation of politics in the era of high modernism, industrialism, technology, and global ideological conflict. In its classical instantiation, the partisan defending his land against the incursion of foreign invaders and regular armies armed with universalistic ideologies exemplified the essence of the political as a distinction between friends and enemies defining a concrete political space, as opposed to abstract and rationalistic ideologies. The partisan, Schmitt suggested, was characterized by four defining features. First, he was an irregular, who was distinct from the regularity of armies understood as technicized organizations. Second, the partisan was distinguished by the intensity of his political engagement: He was defined by his partiality and by the exclusively political distinction he operated between friends and foes. Third, the partisan represented a mobile and flexible force that moved in and out of combat as the situation required. Fourth, and quite crucially, the partisan was 'telluric', in the sense that he was tied to the defence of his homeland; his political engagement was concrete, defined in spatial terms, and his hostility was thus limited and bounded by this space. It was also, decisively, of a defensive nature; the partisan was a resistant. The partisan, in other words, concentrated into an individual figure some of the fundamental characteristics of Schmitt's concept of the political: spatial concreteness, limited nature of hostility, and friend-foe distinction. The fate of the partisan in the modern world, which was the prima facie subject of the book, must be understood also as the fate of Schmitt's concept of the political in the Sputnik era.

The telluric nature of the partisan, his contraposition to the technical regularity of organized armies, made him an obsolete figure that ran the risk of being dépassé in a globalized techno-industrial world. The fate of the partisan in modern times mirrored and 
expressed the fate of the political in an industrial society in which the political was eroded by the nihilistic and neutralizing powers of technology. In this emerging context, Schmitt wrote, the old partisan 'appear[ed] comical' (Schmitt, 2007a: 76). 'When the internal, immanent rationality and regularity of the thoroughly-organized technological world [had] been achieved ... the partisan [became] perhaps nothing more than an irritant'. He was essentially an oddity, a relic of the past bound to disappear, Schmitt wrote in a blunt formula, 'like a dog on the Autobahn' (ibid.: 77).

Schmitt's diagnosis of the crisis of the political in technical-industrial society was not particularly original, and one can find similar analyses in contemporary mainstream social science. In The End of Ideology, for instance, the sociologist Daniel Bell had already developed a similar argument: Politics was on the wane in industrial societies where intense political divisions had given way to a general consensus. Even the division between East and West, dramatized by the confrontation between the two world powers, concealed a deeper convergence. The political had migrated to new spaces, to former colonies where revolutionary and modernizing ideologies were on the rise, 'in particular the ideologies of industrialization, modernization, Pan-Arabism, color, and nationalism' (Bell, 2000: 403). As he wrote about the shift of politicized partisanship to colonial spaces, Schmitt was not breaking new ground. Nor was Schmitt the only reactionary thinker who turned to the partisan in order to bemoan the dehumanizing reign of technology and the retreat of the political in the 1960s. Ernst Jünger had published two pamphlets, Der Waldgang (published in 1951 and later translated into English as The Forest Passage) and Der Weltstaat (1960), which dealt with the themes of politics, resistance, and technology in the context of the passing of the old European order. Against the expanding technological powers of the state, Jünger adopted the partisan as a symbol of the defence of individual freedom, withdrawing to the primordial forest. Eventually, in Der Weltstaat, he seemed to accept the ineluctability of the technical unification of the world and to anticipate the emergence a demilitarized world state in which the political would have completely disappeared (Jünger, 1960: 73-5). Theory of the Partisan also draws explicitly on another book, inspired by Jünger: Rolf Schroers' Der Partisan. Ein Beitrag zur politischen Anthropologie (1961). According to Schmitt, who commended the book, 'Schroers... [saw] in the partisan the last resistance against the nihilism of a thoroughly technologized world, the last defender of species and soil, and ultimately, the last man'. The partisan as the last refuge of the political in a world taken over by technology and industry was thus a topos of the postwar political reaction.

Yet, what distinguished Theory of the Partisan from the rest of this conservative literature was Schmitt's refusal to see the partisan exclusively as a residual figure inevitably fading away as the world is increasingly unified by technological progress. In the political nature of partisan violence, Schmitt saw the kernel of a development that became central to the postwar era. While in the classical European order the partisan had been deployed on the margin of limited, bracketed war between states that did not know absolute enmity, in an age of revolutionary ideologies characterized by the disappearance of state sovereignty and the unification of the world by technology (and in particular by the threat of nuclear annihilation), the partisan became the essential figure of political warfare and moved to the centre stage of what Schmitt described in his writings of the period as a 'world civil war'. Far from making the partisan irrelevant, the 
technical-industrial unification of the world made him absolutely central, while creating the conditions for unfettered political violence.

Schmitt thus introduced the possibility of a transformation of the partisan into a technological, deterritorialized, 'motorized' partisan. The partisan might be inextricably tied to a primordial dimension of human life threatened by technology, 'but what if this human type that until now [had] produced the partisan succeed[ed] in adapting to the technical-industrial environment...?' The absorption of the partisan within the technical-industrial planetary order was Schmitt's central hypothesis. Contrary to Jünger's woods-bound resistant or Schroers' political fossil in the making, Schmitt's motorized partisan rushed to new frontlines as he was drawn into the rational-technical order; he was 'linked to an information network with clandestine transmitters and radar' (Schmitt, 2007a: 76). In this transformation, he did not lose his political attributes. He might be dependent on technical supply systems and political patronage, but in the saturated space of the global Cold War, these complex power games reopened a space for political agency: 'If several interested third parties become involved concurrently, then the partisan has space for his own politics' (ibid.: 75). In a world of sociotechnical regularities, he remained an irregular, who acted on the basis of absolute friend-foe distinctions that did not know any limitations or bracketing. The motorized partisan was the political hidden in plain sight at the heart of the techno-industrial order.

The 1960s and 1970s, therefore, were not a time of depoliticization and neutralization for Schmitt. The period witnessed the displacement of the political to new spaces, whether the postcolonial space or even outer space, which he referenced throughout the book by discussing the politics of Mao or the possibility of 'cosmo-partisans'. Theory of the Partisan and other texts of the same period thus indicate a departure from Schmitt's previous considerations about the end of the political. In the 1930s, The Concept of the Political entertained the idea of complete depoliticization: 'If . . the distinction between friend and enemy ceases even as a mere possibility, there will only be a politics-free weltanschauung, culture, civilization, economy, morals, law, art, entertainment, etc. but there will be neither politics nor state' (Schmitt, 2007b: 53, 54). Schmitt now rejected this perspective, and sought to reinscribe the essence of the political in the technoindustrial present. His motorized partisan served precisely this purpose: It was a cog in the machinery of the technologically unified and allegedly pacified world state. No matter how technologically integrated the world became, it remained political.

The very existence of the motorized partisan was the demonstration that not all questions of the technical-industrial era could be transferred to the plane of rationalism and technology and be resolved at that level. On the contrary, technical progress opened new spaces of appropriation and distribution, the possibility of new nomoi, 'and thereby only intensifie[d] the old questions' (Schmitt, 2007a: 80). Schmitt insisted that the framework he had elaborated in the 1930s was still valid. His introduction to the 1971 Italian edition of The Concept of the Political made this claim explicit. Technological progress, he wrote, might well generate automatically and immediately its own ideological justifications; it might well create ever greater expectations to put 'an end to all politics'; it might view humanity as a 'unified, basically pacified society' in which 'enemies no longer exist[ed], but [had] become conflict partners; and world politics must be replaced by world police'. Nonetheless, 'today's world and modern humanity 
are still very far from political unity. Policing is not apolitical'. Technology both lifted the restrictions on political enmity and shifted political violence within an increasingly unified world society, where it took the form of internal violence and partisanship: 'World politics is a very intensive politics that stems from a will to paninterventionism; it is a particular form of politics and certainly not the nicest, namely the politics of world civil war' (Schmitt, 1988: 272).

Maintaining the basic framework of The Concept of the Political, or what Schmitt called the 'old questions', implied considering with suspicion the self-image of techno-industrial society as a depoliticized one. Theory of the Partisan contained a sceptical take on the notion that the rationalization of social life under technoindustrial conditions gradually shrank the space of the political and paved the way towards its complete disappearance. Only a blind and uncritical acceptance of the discourse of modernization theorists could create the impression of an impending end of the political and prevent one from discerning its evolving forms. Only 'when the internal, immanent rationality and regularity of the thoroughly-organized technological world has been achieved in optimistic opinion... [will] the partisan [become] perhaps nothing more than an irritant'. Yet, for Schmitt, such an opinion was nothing more than a 'technologically-focused fantasy'. A more serious - and more pessimistic - view made for the possibility, next to the worst-case scenario of atomic annihilation, of 'a margin of limited and bracketed war', that is, of a new form of politics (Schmitt, 2007a: 77-9).

\section{Hobbesian cybernetics}

Despite adumbrating these political spaces carved out in a world globalized through technological means, Schmitt remained very tentative about the forms of politics they could allow for, and considered that they did not include the kind of fundamental decisions that defined true politics. What set him apart from other conservative critics of technological modernity, however, was his refusal to accept that politics could entirely disappear.

In his interwar writings, Schmitt had lamented that the development of the liberal state emptied the classical concepts of politics of their force. Law was replaced by regulations and measures; social and economic interests corroded the law-giving force of the state; democratic pluralism endangered the ordering power of the Leviathan. This line of thought informed the most conservative strands of postwar German sociology, and was developed in particular by Helmut Schelsky and later by his student Niklas Luhmann. Elaborating on Schmitt's concept of the political, Schelsky had suggested that sovereignty was no longer the capacity to decide upon the exception; in industrial society, it had become conflated with the deployment of technological assets. Yet, Schelsky immediately pointed out, modern technical systems generated their own solutions and prescribe decisions; sovereignty ended up being diluted in these sociotechnical networks. Politics as decision simply disappeared, and any talk of a political 'decision' could only be metaphorical. In this context, asked Schelsky, 'What [was] still "political"?' Who represented this new 'reason of state'? Who was the 'statesman of the "technical state"?' Modern technology dispensed with the need for legitimacy and 
was immediately depoliticizing: One ruled 'while [technology] function[ed] and only so long as it function[ed] optimally'. Technology, Schelsky went on, '[did] not need any other decision than the decisions over technical principles'. As a result, the statesman of the technical state was "not a "decision-maker" or a "ruler," but rather an analyst, a builder, a planner, an executer. In this framework, politics in the sense of normative willformation is in principle removed from this space and degraded to the rank of mere resource for the imperfections of the "technical state"" (Schelsky, 1961: 25). The result was the gradual disappearance of the political understood as the capacity to decide: 'The better the technique and the science, the more restricted the space for political decision' (ibid.: 28). Decisions became dependent variables, entirely determined by the inner workings of the technical system, and did not express any form of sovereignty located above and beyond the system.

This may have been a sociological riff on Schmitt's earlier positions, but for Schmitt, this description was no longer adequate for the times. He referred somewhat dismissively to Schelsky in the context of a review essay dealing with recent interpretations of Hobbes (Schmitt, 1965). Schelsky himself had written his 1939 Habilitationschrift on Hobbes, when he was still a young Nazi activist. ${ }^{4}$ More importantly perhaps, in the 1960s Hobbes offered a fertile ground for thinking through the articulation of industrial society and political decision. Not surprisingly, Schmitt's discussion of Hobbes now departed radically from his earlier interpretation. In 1938, he had faulted Hobbes for his choice of a mechanical symbol for the state and for the resulting failure to produce a political myth commanding obedience beyond mere rational argumentation (Müller, 2010). In 1965, in a complete reversal, Schmitt saw in Hobbes a political theologian who saved the political by locating the soul of the state outside and above its technical, machine-like body. What made the authority of Hobbes' sovereign binding was not its reasonableness, but its capacity to elicit obedience after the model of God's command. ${ }^{5}$ Any understanding of Hobbes as the founder of political 'science', Schmitt now suggested, fundamentally missed his relevance for a theory of the state:

In reality, Hobbes is not a scientist, nor is he a technocrat. His thought is for this reason fundamentally ill-fitted to, and indeed incommensurable with an age of scientifictechnical civilization, because a question such as the Hobbesian quis judicabit? is not concerned at all with technical 'objective necessities' [Sachgesetzlichkeiten]. The inherently coherent functionalism of these objective necessities eliminates the notion of a personal decision, and it does entirely so 'by itself,' out of its own 'logic,' without any decision. To speak of 'decisions' in this respect would be as absurd as pretending that the alternating green and red signals of traffic lights were a series of 'administrative acts' or decisions, in order to construct them juridically and insert them into a system of traditional administrative law - something quite unscientific, because naively anthropomorphic. (Schmitt, 1965: 67)

Instead, the value of Hobbes' theory of the state was to suggest that such cybernetic systems did not substitute for the political. Schmitt seemed to follow Schelsky's sociological analysis of industrial society, but only up to a point, before suddenly dismissing it and drawing a radically opposed conclusion: 
If this is already clear in the domain of unpolitical traffic laws, it is even more so for the realm of the political! In scientific civilization, one can follow Helmut Schelsky ... and speak of the 'fictitious decision-making [Entscheidungstätigkeit] by the politicians' to whom these highly complex objective necessities prescribe the solution to their political duties. Very well. These rationalized orders prescribe solutions, i.e. answers. But by themselves they cannot ask questions, least of all Thomas Hobbes' question quis judicabit? No cybernetic machine is yet so perfect as to be capable of reaching beyond its own premises and asking the question quis judicabit? in the sense of the Hobbesian philosophia practica. In relation to the machine, which by itself provides solutions and answers, the decisive question of quis judicabit? or quis interpretabitur? is specified as the question quis interrogabit? This is the question of who poses the question and who programs the machine that, in itself, remains external to the decision. (Schmitt, 1965: 67-8)

The cybernetic steering mechanisms that defined the governance of industrial society and shaped its (a)political imaginary could not replace political decisions. If anything, the locus of the sovereign decision had shifted, but sovereignty was not a fixed instance. That Schmitt touched upon cybernetics in the context of a discussion of Hobbes should not be surprising. If technical-industrial society set the stage for a world civil war characterized by the absolute intensity of the antagonists' engagement, then the contemporary situation was not unlike the one Hobbes was facing and reacting against by generating a new theory of the state. The development of cybernetics, the importance of techno-industrial systems in determining the direction of social development, the erosion of political distinctions under the development of technology on a planetary scale set the stage for a new disorder that called for a sovereign decision. Schmitt's return to Hobbes in the 1960s was thus part of an oblique rhetorical strategy allowing him to reframe the cultural critique of technology in terms that were central to his political theory: In a situation of global civil war caused in part by the breakdown of political distinctions under the impact of technology, the most urgent task was to recover a capacity to think politically. And this, for Schmitt, meant first and foremost realizing that the new world Leviathan was not just a mechanistic sociotechnical assemblage deprived of a soul, but the outward façade of a political decision.

In Schmitt's view, the technical-rational orders that for Schelsky imparted solutions were not capable of formulating problems, and thus did not erase the need for decisions. At most, the decision was now located at one remove, and obscured by these sociotechnical apparatuses. But this only meant that they concealed a decision and a specific politics - that is, that the 'technologically-focused fantasy' that posited the replacement of politics by technology was itself politics. For Schmitt, even the end of all politics was still a politics. The mistake of Schelsky, Jünger, Schroers, and Kulturpessimisten of all stripes was to take at face value the self-image of industrial society and simply turn into despair the optimism of modernization sociologists. Unlike them, Schmitt posited the political against the pervasive powers of technology. This was not a sociological analysis, but a political stance. There was indeed something of a performative speech act in Schmitt's doing so, not to say wishful thinking: The political was still present because Schmitt said it was, in the sense that he reintroduced an element of discrimination, and therefore of politicization. 
Schmitt's discussion of Hobbes allows us to better understand Schmitt's take on cybernetics. There are very few references to decision technologies such as cybernetics or game theory in Schmitt's writings. When they appear, they are treated as generic instances of technology, or perhaps more appropriately as the extreme form that technology takes when it pretends to replace politics. As the traffic light example suggests, cybernetic systems may display a semblance of purposiveness and determination, but they are fundamentally unable to make decisions; the true decision-making power always lies outside them and exceeds the bounds of rational systems, just as sovereignty is defined by being in excess of the legal order it authorizes. The cybernetic machine is apolitical because it only follows an internal program over which it cannot elevate itself; it cannot 'reach beyond its own premises'. In a gloss on Schmitt, Jacques Derrida later expressed this irreconcilable tension by suggesting that a true political decision was fundamentally heterogeneous to calculation and rule-like protocols. A decision, or at least a political decision, bore upon things that were not commensurable and could not be brought under a common measure and calculated. A decision 'that [did] not experience the undecidable would not be a free decision, it would be only the programmable application or the continuous unfolding of a calculable process' (Derrida, 1994: 53, 58). Speaking of decisions in the context of cybernetic systems cannot be but an improper use of the term, a metaphor or a conceptual stretch.

More surprisingly, Schmitt also denied any political character to game theory, which one would have expected to be more akin to an understanding of the political as premised on friend-foe distinctions. Game theory could indeed allow for the sort of regulated duel between sovereigns that Schmitt had extolled in The Nomos of the Earth as the greatest achievement of the classical European order. With its capacity to reveal sets of mutual rules through antagonistic iterations, game theory might indeed have been considered some modern and technical form of 'bracketing' of violence. Instead, Schmitt dismissed it. Game theory made a brief appearance in Schmitt's 1963 response to the comments that Leo Strauss had written in 1932 about The Concept of the Political. Strauss had zeroed in on Schmitt's use of the word 'entertainment' as a symptom of Schmitt's disgust for a world from which politics (and thus, for Strauss, moral seriousness) would be absent. ${ }^{6}$ Taking in Strauss' comment, Schmitt later acknowledged that his use of the term was too cavalier. Instead, he wrote, he should have used the term 'play [Spiel]', in order to emphasize the opposition to seriousness.

Schmitt's response was a little cryptic, and did not elaborate on the reasons why Spielas-play would have been a more precise concept than 'entertainment', but he referred the reader to Hamlet or Hecuba, his short essay on Hamlet published a few years earlier. The theatrical play (Spiel) Schmitt had in mind there was one that was not yet bounded by the strict rules of composition and unity defining French classical theatre and mirroring the capacity of sovereign power to order space and time. It reflected the specific historical situation of Shakespearean drama, a tumultuous period of transformation of the English monarchy in a direction that put it at a variance with the continental absolutist states - one that would eventually turn England into a sea-bound, industrial power. In this situation, in which monarchic power could exist only by composing with religious groups and social forces, relationships of enmity were indeed pre-political, and the Baroque dramaturgy of power was not centred on the state, as it was on continental 
Europe. The Shakespearean drama was still caught in a primal, pre-political dimension (a 'barbaric' one, said Schmitt) and its concrete historical content registered these conditions, in which political antagonisms did not yet upgrade to stately politics (Schmitt, 2009: 62-4). The play thus staged specific forms of antagonisms, yet they were not fully political. Not surprisingly, Hamlet was also a play on indecisiveness. If 'play' would have been better than 'entertainment' to describe a world in which the capacity for political decision had disappeared, then, it was in that specific sense.

While at first sight this has nothing to do with technology and cybernetic decision, Schmitt sought to clarify further the semantics of Spiel by offering an unexpected term of comparison. Spiel as play was fundamentally different from Spiel as game. It was

different from the mathematical theory of 'games' which is a theory of games and its applicability to human behavior, such as that expressed in the book by John von Neumann and O. Morgenstern, Theory of Games and Economic Behavior (Princeton University Press, 1947). Here friendship and enmity are simply accounted for and both dispensed with, like in chess the opposition of white and black has nothing to do with friendship or enmity (Schmitt, 1963: 120-1). ${ }^{7}$

If Elizabethan drama staged proto-political forms of opposition, these remained concrete and effective, even if they did not ultimately refer to a space of politics unified by a sovereign will. Game theory, on the contrary, could not capture true opposition because it was utterly abstract; it could not approximate politics. The notion of Spiel used in the sense of 'game' also appeared in Theory of the Partisan when Schmitt discussed Lenin's conception of revolutionary war. Revolutionary war was genuine war because it was premised on absolute enmity, unlike conventional European international law, which recognized opponents bound by common rules but did not identify them as true enemies. Lenin drew the distinction between Voina (war) and Igra' (game), and he found the latter, according to Schmitt, 'contemptible and ludicrous' (Schmitt, 2007a: 52). While Schmitt certainly admired the classical bracketing of war achieved through the jus publicum europaeum, he nonetheless found contemptible and ludicrous the stylized duel, the rules of which game theory allegedly captured.

This is all the more surprising since, at the end of Theory of the Partisan, Schmitt adumbrated a new possibility of bracketing: Under nuclear conditions, 'a margin of limited and bracketed war with conventional weapons and even means of mass destruction could be outlined'. In this situation, world powers could engage in 'a controlled war... something like a dogfight. It would be the apparently harmless play of a precisely-controlled irregularity and an "ideal disorder," ideal insofar as it could be manipulated by the world orders' (Schmitt, 2007a: 79). The expression 'ideal disorder' here must be understood in opposition to another notion that Schmitt had used repeatedly, that of 'concrete disorder': a situation of total conflict, of war of all against all to which a decision put an end as it manifested its sovereignty (Schmitt, 2004: 62). An ideal disorder was one that was already rationalized and thus framed within parameters that could be manipulated following strategic rationality - the kind of formalized war of minds that game theory provided, a rational bracketing of conflicts in which the limiting rule-like normativity no longer took a legal, but an algorithmic form. And yet, for Schmitt, it remained beneath politics. 
The overview of Schmitt's discussion of technology in the 1960s suggests that despite an effort to think through new articulations between politics and technology (as in Theory of the Partisan), he ultimately remained tied to a vision of technology as an essentially depoliticizing force. This is nowhere more apparent than in his cursory and dismissive references to cybernetics and game theory. Schmitt did not see what was specific about these technical mechanisms of governance, and failed to consider the possibility that such technologies were not antithetical to politics or, to use his words, 'external to the decision', but instead a particular extension of it. When he turned the question 'quis judicabit?' into the question of who programs the machine, he touched upon a key issue without realizing how consequential it was for his own argument. These technical systems are not a level or a layer external to a prior decision. Rather, their design gives a particular form and extension to a prior decision, while at the same time obfuscating it. Far from replacing politics, these technical orders are imbued with it, and in many ways patterned after it.

Schmitt's insistence that technological progress only 'intensif[ied] the old questions' without fundamentally altering them, leaving the separation between technology and politics intact, also prevented him from seeing how much these transformations incorporated some of his own insights and offered a new figuration of the autonomy of the political. How cybernetic systems replicated some fundamental assumptions of politics, assumptions that were central to Schmitt's own definition of it, is the issue I now turn to.

\section{The new face of decisionism: Cybernetics and the autonomy of the political}

While nothing indicates that Schmitt had more than a cursory knowledge of cybernetics or game theory, he nonetheless had good reasons to view with suspicion the development of the decision sciences and system theory. The notion of system was introduced in political science against the theory of sovereignty that Schmitt defended and in support of a liberal project that he abhorred. ${ }^{8}$ In the first pages of The Political System, David Easton had suggested that systems theory was a pushback against political theology. The book was aimed against the 'mood in Western civilization directed against the use of scientific reason'. 'The present epoch', Easton wrote, 'may well be the beginning of a long period of the decline of men's faith in reason'. The Enlightenment faith 'in the ability of the kind of reasoning implied by scientific method to solve social problems, empirical and even moral' was under attack (Easton, 1953: 6-7). Easton was particularly worried by a 'movement back to theology' that emphasized spiritual ideals detached from empirical reason, and by the kind of 'traditionalism' for which 'reason ... must yield to the greater wisdom of prejudice, tradition, and accumulated experience knowable largely through history' (ibid.: 19, 21). Cybernetics and system theory were essentially oriented against the Schmittian concept of the political.

Second, at least in political science and political theory, cybernetics was explicitly conceived as an alternative to decisionistic representations of politics. While it is not possible to specify the complex relationship between cybernetics and rational choice within the confines of this section, suffice it to say that theorists of cybernetics explicitly posited their field against representations of human action as an ongoing sequence of 
rational decisions. 'Much of the work in developing [cybernetic] theories', John Steinbruner wrote, 'has been directed precisely at the problem of explaining highly successful behavior (usually called adaptive) without assuming elaborate decision-making mechanisms' (Steinbruner, 1974: 48). Adaptive and vicarious learning, not purposive calculation, was the fundamental principle of cybernetic models. The multitude of feedback loops allowing for constant correction tended to dissolve any notion of decision within an open-ended environment. While the target of cybernetics was the unrealistic notion of a wholly rational calculator assumed by rational choice theory, any decisionistic vision of politics was collateral damage. ${ }^{9}$ The looping circuitry of cybernetic systems flattened the sphere of politics by removing from it any sovereign terminus ab quo and allowing all elements to contribute to the operation of the system. From a Schmittian point of view, such a flat and open-ended landscape deprived of verticality and transcendence could be anything but political.

It was thus easy for Schmitt to find in the statements of cyberneticians arguments that seemed to confirm his own wariness about the depoliticizing power of technology. He could also find support in the pronouncements of some of the more circumspect liberals who, like Judith Shklar, considered systemic theories of the political to 'de-ideologize politics' (Shklar, 1964: 15). And yet, in doing so, Schmitt was uncritically subscribing to what he himself had denounced as a 'technologically-focused fantasy' and missing some crucial aspects of the decision sciences, whether cybernetics or game theory. That cybernetics or game theory pretended to replace the messiness and irrational nature of traditional politics with a science of complexity or more rational decisions does not mean that they actually did. First, they never really replaced politics. But in depicting the political process using a mechanistic language inspired by information theory, they obfuscated the real logics of decision behind a facade of dynamic equilibriums resulting from the self-steering capacity of complex systems that individual minds were illequipped to comprehend, let alone to govern. ${ }^{10}$

More importantly, however, cybernetics incorporated old concepts of steering that brought with them their share of political lore. This set cybernetics apart from other generic 'technologies' that could be counterpoised to politics. In remaining wedded to the hypothesis of the depoliticizing force of technology, Schmitt prevented himself from grasping what was specific about the cybernetic models of decision-making and government. What made cybernetics and game theory so threatening for politics, in Schmitt's view, was that these conceptual languages were morphologically similar to politics, and thus too close for comfort. Cybernetics essentially replaced decisions with an ersatz of purposiveness, as system theorists recognize. ${ }^{11}$ Politics was no longer the result of a prior and superior decision, but the outcome of systemic adjustments. Whatever 'decisions' were included in such systems were algorithmic nodes that always referred to some form of 'input'; no proper sovereignty could obtain in such a setting. In other words, because cybernetic systems were isomorphic to politics and neutralized it at the same time, the relationship between cybernetics and politics was not unlike the relationship between politics and theology that Schmitt himself had done so much to specify.

One could thus paraphrase the most famous passage of Schmitt's Political Theology and suggest that 'all significant concepts of the modern theory of systems [were] 
technologized political concepts'. In fact, this had not escaped the attention of some cyberneticians. In The Nerves of Government (1963), Karl Deutsch had pointed at the similitude between traditional notions of sovereignty and the transitivity characteristic of rational systems. In game theory, transitivity essentially meant that if one preferred A to $\mathrm{B}$ and $\mathrm{B}$ to $\mathrm{C}$, then one also preferred $\mathrm{A}$ to $\mathrm{C}$. Game theoretical representations of politics assumed that 'the political decision system of each country must be transitive'. Game theory, Deustch argued, assumed 'that in every political system there ought to be one sharply defined place of ultimate decision', something that was perfectly compatible with Schmittian notions of sovereignty. In fact, such representations of political systems had obvious antecedents: 'If all important decisions are concentrated at one point, and if decisions made at that point tend to override all decisions made elsewhere in the system, the performance of the system may resemble the situation of concentrated sovereignty, familiar from the absolute monarchies of seventeenth- and eighteenth-century Europe' (Deutsch, 1963: 54-5, 209). What Deutsch's musings suggested was not only that cybernetics was an intellectual project capacious enough to accommodate conventional notions of sovereignty and translate them into the language of 'systems', but that traditional forms of politics were indeed central to the definition of cybernetic rationality. As I have pointed out elsewhere, while they seemed to be prima facie antithetical to early decisionism and its anti-rationalism, notions of 'rational choice' proved to be perfectly acceptable vehicles for a modernized decisionism that found its justification not in theology but in the 'scientific' analysis of decision-making. ${ }^{12}$ A self-described former 'decisionist' (and former Schmitt disciple) such as Harvard political scientist Carl Friedrich had no major difficulty equating the 'rationality' of rational choice with the authoritative force that put an end to endless deliberative loops and generated the decision - that is, the decisionistic fiat (Friedrich, 1964: 180). Far from necessarily accelerating the decline of the state's law-giving force by opening it to all kinds of social inputs, cybernetics could also support self-referential representations of political command: As a number of commentators have noted, Schmitt's insistence on the contentindependence of legal decisions and their self-validation later found echoes in Luhman's cybernetic conception of the reproduction of the legal system under autopoietic conditions (Bolsinger, 1998; Fischer-Lescano and Christensen, 2012). Nothing, indeed, predisposed cybernetics to run necessarily counter to traditional notions of power and sovereign decision, even if it played that role in some contexts.

Legal theory was not the only field where cybernetics supported rather than neutralized political decisions. In international relations theory, perhaps the discipline most concerned with Schmittian friend-foe distinctions, starting in the 1960s 'neorealism' provided a cybernetic reinterpretation of traditional notions of the balance of power, only euphemizing the need for decisions behind the semblance of a self-regulating international 'system' maintaining homeostasis on its own, seemingly independently from any individual decision (Bessner and Guilhot, 2015). Traditional notions of balancing were refurbished as principles of systemic or bipolar stability in a conceptual shortcut allowing for historical theologico-political concepts to morph seamlessly into cybernetic notions. In that sense, David Bates is absolutely right, in his contribution to this special issue, to emphasize the similarities between Schmitt's katechon and a cybernetic, counter-entropic force postponing disorder, and to draw our attention to the 
'decisionistic element in early cybernetic thinking' (Bates, 2020). But it is precisely such parallels that should make us wary of the temptation to turn to Schmitt's decisionistic concept of the political as an effective counterforce to the neutralizing power of decision technologies. As we have seen, Schmitt's insistence on upholding the counterposition of politics and technology in the 1960s condemned him to miss the translation of some of his own insights into the new political language of cybernetics. Unable to conceive of politics without verticality and transcendence, Schmitt saw the self-referentiality of cybernetic systems as the epitome of depoliticization.

Schmitt did not, and maybe could not, realize that the cybernetic imagination that had taken over political theory was a modernized instantiation of the autonomy of the political. As new social movements emerged, formulating new demands and expressing an increasing capacity for collective determination, the migration of politics into technomanagerial systems ensured the insulation of government from social demands; this was indeed the essence of Schmittian politics. Except that it was no longer presented in the decisionistic terms of 'politics-as-decision' characteristic of Schmitt's political theory, but in terms of 'politics-as-systemic complexity' characteristic of postwar social science. Reconceptualizing in cybernetic terms critical domains such as foreign policy or economic policy did not erase the need for actual decision, as system theorists knew well, yet it contributed to shielding these decisions from scrutiny and democratic oversight, maintaining somewhere in the system the sovereign capacity to decide upon the exception (Bessner and Guilhot, 2018).

In retrospect, it is indeed surprising that Schmitt did not seem to realize that the science of complexity was first and foremost used to preserve the political from the encroachment of societal forces. One can get a sense of this by perusing one of the political manifestos of the time, the 1975 report of the Trilateral Commission, The Crisis of Democracy (Crozier, Huntington and Watanuki, 1975). The goal of this report was nothing less than the recovery of the autonomy of the political against new social and democratic claims, and it attempted to do so in the name of systemic complexity. Its authors argued that industrial societies suffered from a democratic overload of their governmental capacity. Traditional mechanisms of democratic will-formation and decision-making could not address adequately the challenges of exceedingly complex industrial societies. Tracing back the vulnerability of government to its decreasing capacity to make decisions in a context of systemic complexity and interdependence, the authors also designated the multiplication of social groups having stakes and intervening in the policy process as one of the vexing aspects government in this context. In such a situation, they suggested, 'decisions have to be taken whose consequences may be far-reaching while the governing process... seems to be capable of producing only erratic results'. The government of complexity could not be left to democratic means, which were too messy, too irrational, and too primitive and ill-equipped to deal with complexity. But by the same token, neither was a regression towards authoritarian government possible, since the latter had the same flaws. As Steinbruner put it, 'a society traditionally concerned with constraining government in the interests of avoiding tyranny must now concern itself with effectiveness. Even if it could be fully accomplished, it would no longer be acceptable merely to follow the established principles of democracy to trust that the outcomes of such a process will be the best attainable, or even 
acceptable.... Achieving effective performance without stumbling into some new form of tyranny is a major issue of coming decades' (Steinbruner, 1974: 6-7). Cybernetics was certainly nothing like the reaffirmation of the sovereign capacity to decide, but it nonetheless served the very purpose that Schmitt had outlined in the 1920s when he inveighed against the capture of the state by social and economic interests: preserving the autonomy of the political.

Schmitt's 1960s comments about technology and their blind spots should be taken as a symptom of the changing relationship between politics and technology characteristic of the cybernetic age, rather than a satisfactory account of government technologies. Cybernetics offered a new image of politics that went beyond the opposition between legalism and decisionism, normative rules and decisions, democracy and dictatorship. It did not so much replace traditional politics as it overlaid it with a new representation of politics in which decisions became more difficult to identify because they disappeared within the technical systems in which they became increasingly embodied. It also provided a new repertoire of legitimacy for political decisions. But it did not fundamentally change traditional representations of society as organic and unified: it only gave them a new conceptual formulation, more befitting post-industrial societies, as Lyotard (1984: 12) later pointed out. ${ }^{13}$ What Schmitt experienced as the crisis of the political in the $1960 \mathrm{~s}$, therefore, was not so much the result of technological advances as it was also the crisis of systemic representations of society. It is not the lesser paradox of Schmitt's thinking on these matters that the time at which he wrote of the technological threat looming over the political was also the end of the cybernetic moment in the social sciences. Both decisionism and its liberalized cybernetic versions registered the crisis of the institutions of modernity and the emergence of a new sociopolitical landscape in which 'information' was no longer sufficiently stable and commensurable to ensure the performance of cybernetic systems or the cogency of political command.

\section{Declaration of conflicting interests}

The author declared no potential conflicts of interest with respect to the research, authorship, and/or publication of this article.

\section{Funding}

The author received no financial support for the research, authorship, and/or publication of this article.

\section{Notes}

1. For a discussion of the deceptive hopes that many place in a Schmittian return to the autonomy of the political, see Hardt and Negri (2017: 42-6). Today, this double-bind appears nowhere more clearly than in the dialectic relationship that shows how decentralized, fluid constituencies can perfectly coexist with the construction of vertical leadership. This dynamic defines modern populism, which finds in new technologies the closest material approximation of a decisional aggregation of the 'people' under the guidance of unmediated and rather traditional forms of authority (Dal Lago, 2017).

2. Schmitt later turned to a very similar argument in his controversy against Erik Peterson. See Schmitt (2008). 
3. Theory of the Partisan has been dubbed a 'revised Concept of the Political' (Caygill, 2013: 106).

4. In this, Schelsky had written critically about Schmitt's 1938 reading of the philosopher. On the sea change that Hobbes studies underwent under the Third Reich, see the remarkably rich article by Tomaž Mastnak (2015).

5. 'Thomas Hobbes' state theory is part of his political theology' (Schmitt, 1965: 52).

6. 'Why Schmitt affirms the political, and, first of all, that he affirms it and does not merely recognize it as real or necessary, is shown most clearly in his polemic against the ideal that corresponds to the negation of the political. Ultimately Schmitt by no means repudiates this ideal as utopian - he says, after all, that he does not know whether it cannot be realized-but he does abhor it... It thus becomes clear why Schmitt rejects the ideal of pacifism (more fundamentally: of civilization), why he affirms the political: he affirms the political because he sees in the threatened status of the political a threat to the seriousness of human life' (Strauss, 2007: 116-17).

7. Schmitt used 'games' in English in the original.

8. On the trajectory of this notion in the postwar social sciences, see Heyck (2015).

9. Not least because rational choice theory offered a civilized substitute for classical decisionism. See, for instance, Shklar (1964).

10. This aspect is developed in Bessner and Guilhot (2015).

11. See the discussion in von Bertalanffy (1968).

12. See Bessner and Guilhot (2018), in particular the introduction.

13. As shown by Stefanos Geroulanos and Leif Weatherby in their contribution to this special issue (Geroulanos and Weatherby, 2020).

\section{References}

Bates, D. (2020) 'The Political Theology of Entropy: A Katechon for the Cybernetic Age', History of the Human Sciences 33(1): 109-27.

Bell, D. (2000) The End of Ideology: On the Exhaustion of Political Ideas in the Fifties. Cambridge, MA: Harvard University Press.

Bessner, D. and Guilhot, N. (2015) 'How Realism Waltzed Off: Liberalism and Decisionmaking in Kenneth Waltz's Neorealism', International Security 40(2): 87-118.

Bessner, D. and Guilhot, N., eds (2018) The Decisionist Imagination: Sovereignty, Social Science and Democracy in the 20th Century. Oxford: Berghahn Books.

Bolsinger, E. (1998) 'Was ist Dezisionismus? Rekonstruktion eines autonomen Typs politischer Theorie' [What is Decisionism? Reconstruction of an Autonomous Model of Political Theory], Politische Vierteljahresschrift 39(3): 471-502.

Caygill, H. (2013) On Resistance: A Philosophy of Defiance. London: Bloomsbury.

Crozier, M. J., Huntington, S. P., and Watanuki, J. (1975) The Crisis of Democracy: Report on the Governability of Democracies to the Trilateral Commission. New York, NY: New York University Press.

Dal Lago, A. (2017) Populismo digitale. La crisi, la rete e la nuova destra [Digital Populism: The Crisis, the Network, and the New Right]. Milan: Raffaello Cortina.

Derrida, J. (1994) Force de loi [Force of Law]. Paris: Galilée.

Deutsch, K. W. (1963) The Nerves of Government: Models of Political Communication and Control. New York: The Free Press. 
Easton, D. (1953) The Political System: An Inquiry Into the State of Political Science. New York: Alfred A. Knopf.

Fischer-Lescano, A. and Christensen, R. (2012) 'Auctoritatis Interpositio: How Systems Theory Deconstructs Decisionism’, Social \& Legal Studies 21(1): 93-119.

Friedrich, C. J. (1964) 'On Rereading Machiavelli and Althusius: Reason, Rationality, and Religion', in C. J. Friedrich (ed.) Rational Decision. New York: Prentice Hall, pp. 177-96.

Geroulanos, S. and Weatherby, L. (2020) 'Cybernetics and the Human Sciences', History of the Human Sciences 33(1): 3-11.

Hardt, M. and Negri, A. (2017) Assembly. New York: Oxford University Press.

Heyck, H. (2015) Age of System: Understanding the Development of Modern Social Science. Baltimore, MD: Johns Hopkins University Press.

Jünger, E. (1960) Der Weltstaat: Organismus und Organisation [The World State: Organism and Organisation]. Stuttgart: Ernst Klett.

Löwith, K. (1995) 'The Occasional Decisionism of Carl Schmitt', in R. Wolin (ed.) Martin Heidegger and European Nihilism. New York: Columbia University Press, pp. 128-69.

Lyotard, J.-F. (1984) The Postmodern Condition: A Report on Knowledge, trans. G. Bennington and B. Massumi. Manchester: Manchester University Press.

Malaparte, C. (2011) Tecnica del colpo di stato [The Technique of Revolution]. Milan: Adelphi. Mastnak, T. (2015) 'Hobbes in Kiel, 1938: From Ferdinand Tönnies to Carl Schmitt', History of European Ideas 41(7): 966-91.

Muller, J.-W. (2010) 'Re-imagining Leviathan: Schmitt and Oakeshott on Hobbes and the Problem of Political Order', Critical Review of International Social and Political Philosophy 13(2-3): 317-36.

Schelsky, H. (1961) Der Mensch in der wissenschaftlichen Zivilisation [Man in Scientific Civilization]. Wiesbaden: Springer Fachmedien.

Schmitt, C. (1963) 'Der Begriff Des Politischen: Text Von 1932 Mit Einem Vorwort Und Drei Corollarien' [The Concept of the Political], 3rd ed. Berlin: Duncker \& Humblot, pp. 120-21. Schmitt, C. (1965) 'Die vollendete Reformation. Bermerkungen und Hinweise zu neuen Leviathan-Interpretationen' [The Reformation Complete: Remarks and Commentaries on Some New Interpretations of The Leviathan], Der Staat 4(1): 51-69.

Schmitt, C. (1988) 'Der Begriff des Politischen. Vorwort von 1971 zur italienischen Ausgabe' [The Concept of the Political: Preface to the 1971 Italian Edition], in H. Quaritsch (ed.) Complexio Oppositorum: Über Carl Schmitt [Complexio Oppositorum: On Carl Schmitt]. Berlin: Duncker \& Humblot, pp. 269-73.

Schmitt, C. (2004) On the Three Types of Juristic Thought, trans. J. W. Bendersky. Westport: Praeger.

Schmitt, C. (2007a) The Concept of the Political, trans. G. Schwab. Chicago: Chicago University Press.

Schmitt, C. (2007b) Theory of the Partisan: Intermediate Commentary on the Concept of the Political, trans. G. L. Ulmen. New York: Telos Press.

Schmitt, C. (2008) Political Theology II: The Myth of the Closure of Any Political Theology, trans. M. Hoelzl and G. Ward. Cambridge: Polity.

Schmitt, C. (2009) Hamlet or Hecuba: The Intrusion of the Time Into the Play, trans. D. Pan and J. R. Rust. New York: Telos Press.

Schmitt, C. (2014) Dictatorship, trans. M. Hoelzl and G. Ward. Cambridge: Polity. 
Schroers, R. (1961) Der Partisan. Ein Beitrag zur politischen Anthropologie [The Partisan: An Essay in Political Anthropology]. Cologne: Kiepenheuer \& Witsch.

Shklar, J. N. (1964) 'Decisionism', in C. J. Friedrich (ed.) Rational Decision. New Brunswick, NJ: Transaction, pp. 3-17.

Steinbruner, J. D. (1974) The Cybernetic Theory of Decision: New Dimensions of Political Analysis. Princeton, NJ: Princeton University Press.

Strauss, L. (2007) 'Notes on Carl Schmitt, The Concept of the Political', trans. J. H. Lomax, in C. Schmitt (ed.) The Concept of the Politicl, trans. G. Schwab. Chicago, IL: Chicago University Press, pp. 99-122.

von Bertalanffy, L. (1968) General System Theory: Foundations, Development, Applications. New York: George Braziller.

\section{Author biography}

Nicolas Guilhot is research professor at the CNRS - Centre de recherches sociologiques et politiques de Paris (CRESPPA). 